\title{
Development of Encyclopedia Boyong Sleman Insekta River as Alternative Learning Resources
}

\author{
Rini Dita Fitriani*, Sulistiyawati \\ Biological Education Faculty of Science and Technology, UIN Sunan Kalijaga Jl. Marsda Adisucipto Yogyakarta, Indonesia \\ Email*: rinidita19@gmail.com
}

\begin{abstract}
This study aims to determine the types of insects Coleoptera, Hemiptera, Odonata, Orthoptera and Lepidoptera in the Boyong River, Sleman Regency, Yogyakarta, to develop the Encyclopedia of the Boyong River Insect and to determine the quality of the encyclopedia developed. The method used in the research inventory of the types of insects Coleoptera, Hemiptera, Odonata, Orthoptera and Lepidoptera insects in the Boyong River survey method with the results of the study found 46 species of insects consisting of 2 Coleoptera Orders, 2 Hemiptera Orders, 18 orders of Lepidoptera in Boyong River survey method with the results of the research found 46 species of insects consisting of 2 Coleoptera Orders, 2 Hemiptera Orders, 18 orders of Lepidoptera in Boyong River survey method. odonata, 4 Orthopterous Orders and 20 Lepidopterous Orders from 15 families. The encyclopedia that was developed was created using the Adobe Indesig application which was developed in printed form. Testing the quality of the encyclopedia uses a checklist questionnaire and the results of the percentage of ideals from material experts are $91.1 \%$ with very good categories, $91.7 \%$ of media experts with very good categories, peer reviewers $92.27 \%$ with very good categories, biology teachers $88,53 \%$ with a very good category and students $89.8 \%$ with a very good category. Based on these results, the encyclopedia is appropriate to be used as an alternative source of learning.
\end{abstract}

Keywords: Boyong River, Insekta, Encyclopedia, Learning Resources

\section{INTRODUCTION}

Boyong River is a river located in the city of Yogyakarta that flows through Sleman Regency. The river stretches starting from the upper reaches of the Merapi Mountain slope which is administratively included in the village of Hargobinangun, Pakem and downstream river boundary in Ngaglik District, Sleman Regency (Suhartini et al, 2014). The upstream area of the Boyong River located on the slopes of Mount Merapi makes it rich in flora and fauna. The condition of the river that has not been much polluted and is still beautiful is the right place to live for animals and plants including insects.

Insect is the highest number of animal species compared to other species in the Arthropod phylum. Insect diversity has a number of $\pm 250,000$ species or about 15\% of the biota in Indonesia (Trista, 2012). Insect is divided into 27 orders. Orders that have the most number compared to other orders are the Odonata, Orthoptera, Lepidoptera, Diptera,

Hemiptera and Coleoptera (Borror, 1992). About $10 \%$ of insects live in water. Insects that dominate in freshwater waters are the Order of Odonata, Coleoptera, Lepidoptera, Hemiptera, Orthoptera (Merrit \& Cummins, 1996). The order of Coleoptera, Hemiptera, Odonata, Orthoptera and Lepidoptera which have the most dominance in freshwater waters is certainly very interesting for further research.

Based on the local potential data of the Boyong River compiled by the KPLS (Community of Environmental and River Lovers) there are 18 types of dragonflies and
23 species of butterflies in the river. Looking at the data, of course there are still many other types of insect species, especially the Order of Coleoptera, Hemiptera and Orthoptera which have not been recorded and can be developed as a source of learning for insects in freshwater waters.

Learning resources are all things that can be used by students and educators to learn the material and learning experiences, in accordance with the objectives to be achieved (Sanjaya, 2009). According to Kasrina (2012) implementing teacher learning activities should utilize learning resources, because the use of learning resources is very important in learning. Optimizing learning resources can be done by utilizing the environment as a learning resource that is not yet widely used in learning, especially learning biology.

Biology learning is included in the study of science studying living things and their lives from various aspects and levels of organization (Sudjoko, 2001). Based on Winaryati et al (2012) science learning is closely related to the use of the environment for learning resources, one of which is by empowering local potentials.

One of the material studied in learning biology is biodiversity which discusses insects. Learning biology of insect material is less effective in class, because the discussion in the material is classification, morphology and role in the environment. The high diversity of insects and terms that are difficult for students to understand makes it difficult to understand the material because there are many Latin names, grouping of insects and 
many of the students are unfamiliar (Henny, 2011). The use of the surrounding environment for learning biology especially this insect material will certainly make it easier for students to understand the material. Learning biology of insect material by using the surrounding environment as a source of learning can be done by utilizing the wealth of insects in the Boyong River, Sleman Regency, DIY.

Utilization of insect wealth in the Boyong River can be packaged in the form of an inventory and developed in the form of learning resources in the form of encyclopedias. According to Tantriandi (2013) the encyclopedia can provide the right explanation and visualization to students so that it makes students interested in learning and know more about the material being studied.

The Boyong River insect encyclopedia that will be developed contains exposure to insect species in the Boyong River of the Order Coleoptera, Hemiptera, Odonata, Orthoptera and Lepidoptera. Each species found is equipped with interesting pictures and scientific names and contains interesting info from the species. Encyclopedia arrangement is also sorted by specific subject and sorted alphabetically so that it is easy to use. The development of the Boyong River insectect encyclopedia is expected to be an alternative source of student learning, so that it can help facilitate the learning process of students, attract interest in learning and can enrich student knowledge.

\section{METHODS}

\section{Research Methods Research}

on existing insect inventory in Boyong River usesmethods survey. This method is carried out by exploring insects in the Boyong River terrestrial area and recording the insects found. The data collection point is based on the segmentation of land through which the Boyong River water flows, namely housing segmentation, paddy segmentation, forest segmentation and bush segmentation.

Making the Boyong river insect encyclopedia for layouting using Adobe Indesign, editing photothat has been taken from field research with Adobe Photoshop, the contents of the material using Microsoft Word and for making the cover using Corel draw X7.

Testing the quality of the insect encyclopedia using thequestionnaire checklist $(\boldsymbol{V})$ where respondents give a check mark in the column provided. Respondents consisted of 1 material expert, 1 media expert, 5 peer reviewers and 1 biology teacher and 15 MAN 4 Bantul students, Yogyakarta.

Data analysis of the results of the encyclopedia quality testing is done by:

1. Collecting all product assessment data from material experts, media experts, pree reviewers, biology teachers and student limited tests, then diananlisi by changing quantitative data into qualitative. This assessment is carried out using ascale Likert with the provisions of SK (Very Poor): 1, K (Poor): 2, C (Fair): 3, B (Good): 4 and SB (Very Good): 5.

2. Calculate the average score of the total number of scores using the formula:

Remarks:

$$
\bar{X}=\frac{\Sigma x}{n}
$$

$\bar{X}=$ Average value of each sub-aspect

$\sum x=$ Number of scores of each sub-aspect

$n \quad=$ Number of scores

3. Change the average score of each aspect of the encyclopedia's assessment to a qualitative value according to the ideal assessment criteria Widoyoko (2013) with the following conditions:

Table 1. Ideal Criteria Category Rating.

\begin{tabular}{lll}
\hline Formula & $\begin{array}{l}\text { Average } \\
\text { score }\end{array}$ & Category \\
\hline $\mathrm{X}>\bar{X}_{i}+1,8 \times \mathrm{x} \mathrm{sb}_{\mathrm{i}}$ & $>4,2$ & $\begin{array}{l}\text { Sangat } \\
\text { Baik }\end{array}$ \\
$\bar{X}_{i}+0,6 \mathrm{x} \mathrm{sb}_{\mathrm{i}}<\mathrm{X} \leq \bar{X}_{i}+1,8 \mathrm{x}$ & $>3,4-4,2$ & Baik \\
$\mathrm{sb}_{\mathrm{i}}$ & & \\
$\bar{X}_{i-} 0,6 \times \mathrm{xb}_{\mathrm{i}}<\mathrm{X} \leq \bar{X}_{i}+0,6 \mathrm{x}$ & $>2,6-3,4$ & Cukup \\
$\mathrm{sb}_{\mathrm{i}}$ & & \\
$\bar{X}_{i-} 1,8 \times \mathrm{xb}_{\mathrm{i}}<\mathrm{X} \leq \bar{X}_{i-} 0,6 \mathrm{x}$ & $>1,8-2,6$ & Kurang \\
$\mathrm{sb}_{\mathrm{i}} \bar{X}_{i^{-} 1,8 \times \mathrm{sb}_{\mathrm{i}}}^{\mathrm{X}>\bar{X}}$ & $\leq 1,8$ & $\begin{array}{l}\text { Sangat } \\
\text { Kurang }\end{array}$ \\
\hline
\end{tabular}

Description:

$\bar{X}_{i}$ : The ideal average that can be searched using the formula:

$\bar{X}_{i:(1 / 2) \text { (highest score ideal + lowest lowest score) }}$ $\mathrm{sb}$ : Ideal standard deviation is searched using the formula:

$\mathrm{sb}_{\mathrm{i}}$ : (1/3) (1/2) (ideal highest score - ideal lowest score)

Ideal of highest score $=$ number of items $\mathrm{x}$ highest score

Ideal of lowest score $=$ number of items $\mathrm{x}$ lowest score

4. Calculates the overall value of the encyclopedia by calculating the overall average score assessment criteria and turn them into qualitative. The results of the assessment are then presented in the form of an idealized presentation table making it easier to read the quality of the encyclopedia in the following way (Sudjono, 2010): 
Presentation of ideals:

$$
(\mathrm{PI})=\frac{\text { Score of the assessment results }}{\text { The highest ideal value }} \times 100 \%
$$

Identification of the results of the assessment is carried out using the provisions of the scale of the presentation of the assessment of product quality the following encyclopedia (Suharsimi, 2007):

Tabel 2. Percentage Scale Product Quality Assessment.

\begin{tabular}{ll}
\hline Interval & Criteria \\
\hline $81 \%-100 \%$ & Very Good \\
$61 \%-80 \%$ & Good \\
$41 \%-60 \%$ & Fair \\
$21 \%-40 \%$ & Less \\
$0 \%-20 \%$ & Very Less \\
\hline
\end{tabular}

\section{Time and Place of}

Research This research was conducted in Boyong River, which is located in Kec. Ngaglik and Pakem, Kab. Sleman, Yogyakarta in February - March 2019.

\section{Tools and Materials}

Tools and materials used in this study include GPS, cameras, insect identification books, tally sheets and stationery.

\section{RESULTS}

\section{Diversity of Insects in Boyong River}

Based on the results of research conducted, 46 species with 15 families from 5 insect orders were found, namely the Coleoptera Order, Hemiptera Order, Odonata Order, Orthoptera Order and Lepidoptera Order. The most commonly found order is the Lepidoptera Order, 20 species and the least are the Coleoptera and Hemiptera Orders, as many as 2 species. The types of insects found are presented in the following table:

Table 3. Insect Species Order Coleoptera, Hemiptera, Odonata, Orthoptera and Lepidoptera that are found in the Boyong River Terrestrial Zone.

\begin{tabular}{|c|c|c|c|}
\hline No & Order & Family & Species Name \\
\hline 1 & Coleoptera & Anobiidae & Anobium punctatum \\
\hline 2 & & Coccinellidae & Epilachna sparsa \\
\hline 3 & Hemiptera & Pyrrhocoridae & Dysdercus cingulatus \\
\hline 4 & & Pentatomidae & Nezara viridula \\
\hline 5 & Odonata & Coenagrionidae & Agriocnemis femina \\
\hline 6 & & Coenagrionidae & Agriocnemis pygmea \\
\hline 8 & & Libellulidae & Brachythemis contaminata \\
\hline 9 & & Platycnemidide & Copera marginifes \\
\hline 10 & & Libellulidae & Crocothemis servillia \\
\hline 11 & & Euphaeidae & Euphea variegata \\
\hline 12 & & Coenagrionidae & Ischnura senegalensis \\
\hline 13 & & Chlorocyphidae & Libellago lineata \\
\hline 15 & & Libellulidae & Neurothemis terminata \\
\hline 16 & & Libellulidae & Orthetrum chrysis \\
\hline 17 & & Libellulidae & Orthetrum sabina \\
\hline 18 & & Libellulidae & Potamarcha congener \\
\hline 19 & & Coenagrionidae & Pseudagrion pruinosum \\
\hline 20 & & Chlorocyphidae & Rhinocypha fenestrata \\
\hline 21 & & Libellulidae & Rhodothemis rufa \\
\hline 22 & & Libellulidae & Zyxomma obtusum \\
\hline 23 & Orthoptera & Pyrgomorphoidea & Atractomorpha crenulata \\
\hline 24 & & Acrididae & Phlaeoba fumosa \\
\hline 25 & & Acrididae & Trilophidia annulata \\
\hline 26 & & Acrididae & Valanga nigricornis \\
\hline 27 & Lepidoptera & Pieridae & Appias libythea \\
\hline 30 & & Nymphalidae & Euploea mulciber \\
\hline 31 & & Pieridae & Eurema'sblanda \\
\hline 32 & & Papilionidae & Grapium agamemnon \\
\hline 33 & & Papilionidae & Grapium doson \\
\hline
\end{tabular}




\begin{tabular}{llll}
\hline No & Order & Family & Species Name \\
\hline 34 & Papilionidae & Grapium sarpedon \\
\cline { 2 - 3 } 35 & Nymphalidae & Hypolimnas bolina \\
\cline { 2 - 3 } 36 & Nymphalidae & Junonia almana \\
37 & Nymphalidae & Junonia athletes \\
\cline { 2 - 2 } 38 & Nymphalidae & Junonia hedonia \\
39 & Nymphalidae & Leptosia nina \\
\cline { 2 - 3 } 40 & Pieridae & Mycalesis Perseus \\
41 & Pieridae & Neptis hylas \\
42 & Nymphalidae & Orsotriaena medus \\
43 & Nymphalidae & Papilio demoleus \\
\cline { 2 - 3 } 44 & Papilionidae & Papilio memnon \\
\hline 46 & Papilionidae & Pelopidas conjuncta \\
\hline
\end{tabular}

\section{Development of the Boyong River Insect Encyclopedia The}

Insect inventory data obtained in the Boyong River based on field research was later developed into the Boyong River Insect Encyclopedia. Development of this encyclopedia begins with selecting good photos from field research and editing them in Adobe photosop. In addition to selecting photos, a theoretical text about insects was also collected. After that, begin encoding the encyclopedia using Adobe indesign. Use of Adobe indesign because it is suitable for layouting and easy to use. Adobe indesign has processing tools for editing, text, and graphics to make it more artistic (Wahyudi, 2007).

The contents of the encyclopedia material are compiled using Microsoft word which is then included in Adobe indesign for service. The use of Microsoft word is because it is young to be used in typing the contents of material for encyclopedias. The contents of this encyclopedia material consist of title, introduction, material and closing pages.

Cover design for the Boyong River encyclopedia was created using Corel Draw X7. The use of Corel Draw is because it is often used to design symbol logos. The superiority in processing's vector-based images Corel Draw also makes good results and is not easily broken if enlarged or reduced (Ulfa, 2016).

The results of the development of this encyclopedia in the form of a color printed book. The contents of the material were printed using 80 gram HVS paper and for the cover it was printed softcover using 260 gram ivory paper withlamination glossy thick enough for cover paper. In total, this encyclopedia contains 129 pages with a size of $22 \mathrm{~cm} \times 20 \mathrm{~cm}$.

The development of this encyclopedia aims to facilitate student learning about insects and increase student knowledge about insects. Insect learning that discusses the classification, morphology and role in the environment, it is necessary to accompany a textbook to get more in-depth material. According to Tantriandi (2013) encyclopedia is one of the learning resources that presents a basic and complete information about a problem. So that the encyclopedia can help students in understanding the material in depth.

Insects are also the most numerous type of animal. A large number certainly makes the taxonomy of insects more, one of which is the order of existing insects. 27 These large orders can be learned easily if the material is arranged coherently and systematically. Sugiyono (2008) material contained in the encyclopedia arranged alphabetically based on certain scholarship. In addition to material arranged in a coherent encyclopedia equipped with pictures that are interesting, relevant and informative. The clear and interesting encyclopedia design can certainly be used as a learning resource that is expected to increase student interest in learning especially insects.

\section{Testing the quality of the Boyong River Insect Encyclopedia}

Testing the quality of the Boyong River Insect Encyclopedia was carried out by passing several assessments. This assessment was conducted by 1 media expert, 1 material expert, 5 peer reviewers, 1 biology teacher and 15 to students at MAN 4 Bantul, Yogyakarta. Assessments provided by material experts, media experts and peer reviewers are used as a reference for the improvement of the Boyong River Encyclopedia before a limited test is conducted on teachers and students. Retrieval of product quality assessment data is carried out using an encyclopedia quality assessment questionnaire. Based on the results of assessing the quality of the Boyong River Encyclopaedia that have been carried out, the following results are obtained:

Evaluation by material consists of components of material content, material presentation and language. The contents of the material get a percentage of ideals of $90 \%$, presentation of material $90 \%$ and linguistics get a percentage of ideals of $93.33 \%$ so that the percentage of ideals obtained an average of $91.1 \%$ which is included in the excellent category. Material experts provide advice to add the anatomical material of insects after the 
morphology of the insect and replace the order of benefits and the role of the insect before the material of the orders so that the material is more coherently arranged.

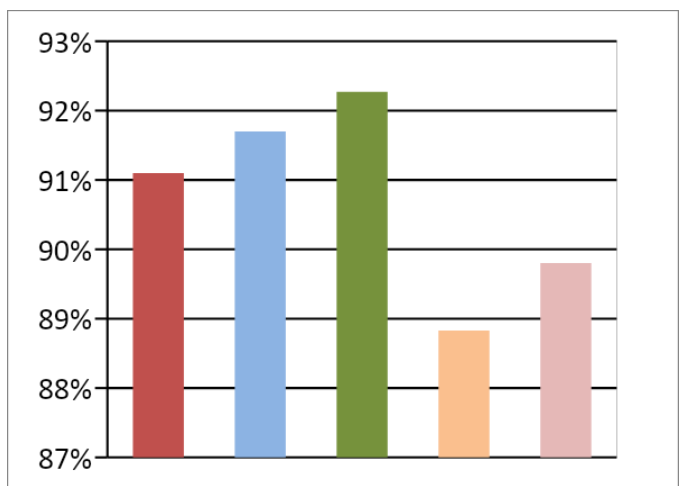

Figure 1. Histogram of the results of the encyclopedia assessment by material experts, media experts, peer reviewers, biology teachers and students.

Table 4. Results of expert material assessment.

\begin{tabular}{llll}
\hline No & Aspect & $\begin{array}{l}\text { Percentage of ideals } \\
(\mathbf{\%})\end{array}$ & Criteria \\
\hline 1 & $\begin{array}{l}\text { Material } \\
\text { content }\end{array}$ & 90 & Very good \\
2 & $\begin{array}{l}\text { Presentation } \\
\text { of material }\end{array}$ & 90 & Very good \\
3 & $\begin{array}{l}\text { Linguistics } \\
\text { Total }\end{array}$ & 93.33 & $\begin{array}{l}\text { Very good } \\
\text { Very good }\end{array}$ \\
\hline
\end{tabular}

Assessment of media experts consists of two components, namely the physical component and the display and graphic components. The physical component scores $100 \%$ and the display and graphics component scores $83.33 \%$. Based on these values, the average percentage of ideals obtained is $91.7 \%$ with a very good category. Media experts provide suggestions for making improvements to the title page by providing illustrated images so that they are more interesting to the reader.

Table 5. Results of media expert assessment

\begin{tabular}{llll}
\hline No & Aspect & $\begin{array}{l}\text { Percentage } \\
\text { Ideality } \mathbf{\%})\end{array}$ & $\begin{array}{l}\text { Category } \\
\text { Quality }\end{array}$ \\
\hline 1 & Physical & 100 & Very good \\
2 & $\begin{array}{l}\text { Display and } \\
\text { graphics } \\
\text { Total }\end{array}$ & 83.33 & Very good \\
& $\mathbf{9 1 . 7}$ & Very good \\
\hline
\end{tabular}

Assessment peer reviewer consists of 3 components, material components, language and appearance and graphics. The material component obtained the percentage of ideals $92.67 \%$, the linguistic component $90.67 \%$ and the display and graphics component obtained the percentage of ideals $92.67 \%$. Based on this value, the average percentage of ideals was $92.67 \%$ with a very good category. Suggestions and improvement was good enough and

Table 6. The results ofassessment peer.

\begin{tabular}{llll}
\hline No & aspect & $\begin{array}{l}\text { Ideals } \\
\text { Percentage } \\
(\boldsymbol{\%})\end{array}$ & Criterion \\
\hline 1 & Material & 92.67 & Very Good \\
2 & Linguistic & 90.67 & Very Good \\
3 & $\begin{array}{l}\text { Display and } \\
\text { graphics } \\
\text { Total }\end{array}$ & 92.67 & Very Good \\
& $\mathbf{9 2 , 2 7}$ & Very Good. This \\
\hline
\end{tabular}

Assessment from the biology teacher was carried out at MAN 4 Bantul. The assessment component consists of 3 components, namely the material, linguistic and display components and graphics. The material component obtained a value of $87.50 \%$, the linguistic component $86.67 \%$ and the display and graphics component obtained a value of $91.43 \%$. In order to obtain an average percentage value of the encyclopedia ideals of $88.53 \%$ with a very good category. The biology teacher gave some corrections, namely on page 14 there was an error in writing classification writing and on page 16 the picture was replaced according to the material point, where the drawing represented an insect that was beneficial to all so it was necessary to replace one picture of the insect guide and one picture of the insect that was detrimental.

Table 7. Biology teacher assessment results.

\begin{tabular}{llll}
\hline No & Aspect & $\begin{array}{l}\text { Percentage of } \\
\text { ideals }(\%)\end{array}$ & Criterion \\
\hline 1 & Material & 87.50 & Very Good \\
2 & Language & 86.67 & Very Good \\
3 & Display and & 91.43 & Very Good \\
& graphics & & Very Good \\
\hline
\end{tabular}

Assessment of student responses to encyclopedias consists above 3 components, material components, linguistic components and display and graphic components. The material component received $88.67 \%$ of students, the language component $87.33 \%$ and the display and graphic components scored $93.33 \%$. Based on these values an average percentage score of $89.8 \%$ was obtained with the very category well. Students give no suggestions and improvements and give an assessment that this encyclopedia is enough to make them easy to learn and can be used as a companion to the existing textbooks. 
Table 8. Results of evaluating student responses.

\begin{tabular}{llcc}
\hline No & Aspect & $\begin{array}{c}\text { Percentage of } \\
\text { ideals (\%) }\end{array}$ & Criteria \\
\hline 1 & Material & 88.67 & Very Good \\
2 & Linguistics & 87.33 & Very Good \\
3 & Display and & & Very Good \\
& graphics & 93.33 & Very Good \\
\hline
\end{tabular}

Based on the overall results of the percentage of ideals that are obtained from material experts $91.1 \%$, media experts $91.7 \%$, peer reviewers $92.27 \%$, biology teachers $88.53 \%$ and from students $89.8 \%$, the overall percentage of ideality is $\mathbf{9 0 . 8 \%}$ with a very good category. The percentage of ideals makes the encyclopedia feasible to be used as an alternative biology learning resource for students. This is in accordance with Ridwan (2013), that the percentage included in the very feasible category is $80 \%-100 \%$.

\section{CONCLUSION}

Based on research, obtained insects of the Order Coleoptera, Hemiptera, Odonata, Orthoptera and Lepidoptera in Boyong River, obtained 46 species from 15 families.

The results of the development of encyclopedias in printed form with test results from material experts as much as $91.1 \%$ with excellent categories, from media experts $91.7 \%$ with excellent categories, from peer reviewers $92.27 \%$ with excellent categories, from biology teachers $88,53 \%$ with a very good category and from students get an assessment of $89.8 \%$ with a good category.

\section{REFERENCES}

Borror, DJ, CA, Triplehorn, NF Johnson. 1992. An Introduction to Study of Insects. Harcourt Brace College Publishers.

Henny, Panggabean NS 2011. Microcession Analysis of Biology Students and Teachers on Animal World Classification
Materials at Helvetia Medan High School. (Masters Thesis). UNIMED.

Kasrina, S. sI. \& Wahyu, EJ 2012. Variety of Types of Microalgae in Swamp Water in Bentiring Permai Village, Bengkulu City as an Alternative Source of High School Biology Learning. Exacta Journal. 10 (1): 36-44.

Merritt, RW, and KW Cummins. 2006 Trophic Relationships of Macroinvertebrates, In: Hauer FR and GA Lamberti (Eds). Methods in Stream Ecology. Academic Press.

Ridwan. 2013. Methods and Techniques of Arranging Thesis. Bandung: Alfabeta.

Sanjaya, Vienna. 2009. Educational Strategy Oriented Education Process Standards. Jakarta: Kencana.

Sudjoko. 2001. Teaching Technology. Bandung: Sinar Baru Al Gensido.Sudjono, 2010):

Sugiyono. 2008. Quantitative Research Methods and R\&D. Bandung: Alfeta. Suharsimi, 2007

Suhartini, Tandjung, D., S., Chafid, F, \& B., Baiquni. 2014 Community Environmental Wisdom in Managing the Natural Resources and Environment of the Upper Boyong River and Code River. Proceedings of the National Seminar Sustainable Development in the Bengawan Solo Watershed, Building Synergy Between Supporting Capacity, Development Programs and People's Welfare. June 19, 2014. UMS. Solo

Tantriadi, Y.2013. Making Interactive Solar System Encyclopedia for Middle School Students. Caliptra: University of Surabaya Student Scientific Journal. 2: 1-17.

Trista, A. 2012. Life Cycle and Population Dynamics of Adult Pradia Stadia of the Acraea Violae Fabricus Butterfly (Lepidoptera: Nymphalidae). (Thesis). Department of Biology, Andalas University. Padang.

Ulfa, K. 2016. Development of the E-ModuleMaterial Coreldraw X6 in Workshop and Entrepreneurship Subjects for High School Students in Class X. (Thesis). Informatics Engineering Education, Yogyakarta State University.

Wahyudi, P. 2007. 36 Hours of Computer Learning Adobe Indesign CS3. Jakarta: Gramedia.

Widoyoko, EP 2009. Evaluation of Learning Programs. Yogyakarta: Student Library.

Winaryati, E., Erma H., \& Akhmad F. 2012. Analysis of the Development of "Local Tourism" Learning Models in Science Learning. LPPM UNIMUS Research Results Seminar. July 7, 2012. UMS. Semarang. 